\title{
Counting the beans: quantifying the adoption of improved mungbean varieties in South Asia and Myanmar
}

\author{
Pepijn Schreinemachers ${ }^{1}$ (I) - Teresa Sequeros ${ }^{2} \cdot$ Saima Rani $^{3} \cdot$ Md. Abdur Rashid ${ }^{4}$. Nithya Vishwanath Gowdru ${ }^{5,6}$. \\ Muhammad Shahrukh Rahman ${ }^{4} \cdot$ Mohammed Razu Ahmed $^{7} \cdot$ Ramakrishnan Madhavan Nair $^{6}$
}

Received: 27 May 2018 / Accepted: 18 April 2019 / Published online: 26 May 2019

(C) The Author(s) 2019

\begin{abstract}
The adoption of improved varieties is an important indicator of the effectiveness of agricultural research. This study quantified the adoption of improved mungbean (Vigna radiata (L). Wilczek) varieties and agricultural practices in Bangladesh, India, Myanmar and Pakistan using an expert elicitation approach. Data were collected from 19 expert panels, organized at subnational levels and involving a total of 259 mungbean experts. The study found that improved varieties were planted on $94 \%$ of the mungbean area in Pakistan, $89 \%$ in Myanmar, 82\% in India and 72\% in Bangladesh. International mungbean breeding research conducted by the World Vegetable Center has had a major impact with its germplasm adopted by an estimated 1.2 million mungbean farmers and grown on 1.8 million hectares of land. Widespread variation in the adoption of improved technologies at subnational levels point to opportunities for increased mungbean yields such as the adoption of line sowing and mechanical harvesting, the use of seed treatments with biofertilizers and biopesticides, and the adoption of better varieties with more comprehensive disease resistance.
\end{abstract}

Keywords Expert elicitation $\cdot$ Impact $\cdot$ Plant breeding $\cdot$ South Asia $\cdot$ Technology adoption

\section{Introduction}

Mungbean (Vigna radiata (L). Wilczek) is a grain legume common to South and Southeast Asia. The crop is popular

Pepijn Schreinemachers

pepijn.schreinemachers@worldveg.org

World Vegetable Center, P.O. Box 1010, Bangkok 10903, Thailand

2 Independent consultant, Bo Yar Nyunt 71, 4D, Yangon 11191, Myanmar

3 National Agricultural Research Center, Agricultural Economics Research Institute, Islamabad, Pakistan

4 Agricultural Economics Division, Bangladesh Agricultural Research Institute, Joydebpur, Gazipur, Bangladesh

5 National Institute of Rural Development (NIRD), NIRD Road, Rajendranagar Mandal, Hyderabad, Telangana 500030, India

6 World Vegetable Center, South Asia, ICRISAT Campus, Patancheru, Hyderabad, Telangana 502324, India

7 World Vegetable Center, BARI Campus, Joydebpur, Gazipur, Bangladesh among farmers as it fits well into the regions' rice-based farming system because of its short duration, low fertilizer requirement, and good performance under heat and drought stresses (HanumanthaRao et al. 2016; Bisht et al. 1998). Mungbeans are also protein- and iron-rich legumes that make an important addition to the cereal-based diets of poor people in South Asia (Nair et al. 2013).

Despite its importance to food and nutrition security, there is a lack of data on the use of improved mungbean varieties and other technologies in South Asia and Myanmar, which hinders strategic investment by governments and international donors. India, Bangladesh, Pakistan and Myanmar planted mungbean on 5.4 million hectares in 2015-2016 (Table 1). India had the largest area, but also the lowest average crop yield ( 0.4 tons/ha as compared to 1.3 tons/ha in Myanmar), which suggests wide variation in growing conditions and the use of technologies.

The objective of this study is to obtain a systematic overview of mungbean production in Bangladesh, India, Myanmar and Pakistan in terms of the use of improved varieties and agricultural practices such as line sowing (as opposed to broadcasting seed), seed treatment, mechanization, and grain storage. Another aim of the study is to deepen our understanding of the role and impact of international mungbean breeding 
Table 1 Basic data about mungbean production for the four countries studied, 2015-2016

\begin{tabular}{llllll}
\hline & Bangladesh & India & Myanmar & Pakistan & Total \\
\hline Area planted (1000 ha) & 175 & 3828 & 1209 & 179 & 5392 \\
Production (1000 tons) & 181 & 1600 & 1597 & 99 & 3476 \\
Average yield (kg/ha) & 1030 & 420 & 1320 & 730 & 651 \\
Farmers producing (1000 s) & 151 & 2734 & 637 & 203 & 3687 \\
\hline
\end{tabular}

Area and production data obtained from: Bangladesh Bureau of Statistics (2015); India: Directorate of Economics and Statistics (2017); Myanmar: Ministry of Agriculture, Livestock and Irrigation (2016); Pakistan: Ministry of National Food Security and Research (2017). Numbers of farmers calculated from the average mungbean area per farmer as reported by Miah et al. 2004; Schreinemachers et al. 2015; Schreinemachers et al. 2017; in Myanmar the number was calculated as the weighted average over the five subnational locations using average mungbean areas per farmer from various unpublished data sources. There is a high level of uncertainty about the actual number of mungbean farmers per country in the region. These objectives were reached through expert elicitation panels organized in 19 major mungbean production areas in the region.

The importance of the study is that it shows extensive impact of international mungbean breeding and a culture of widespread collaboration and germplasm sharing among national agricultural research systems (NARS). The results also reveal gaps in the adoption of improved varieties and agricultural practices for some locations, which could guide future investment in research and extension. Furthermore, the study makes an important contribution to the method of expert elicitation by widening the scope of such studies from a narrow focus on improved varieties to a broader range of complementary innovations.

\section{Materials and methods}

\subsection{Mungbean improvement in Asia}

Mungbean improvement research is conducted by national agricultural research systems in Bangladesh, India, Myanmar and Pakistan and in other Asian countries such as China, Thailand, Vietnam, and the Philippines as well as in Australia. Mungbean has also been a mandate crop of the World Vegetable Center (WorldVeg) for over 40 years. The Center's genebank holds 14,187 genebank accessions of mungbean (the genebank's second largest collection after soybean) and has shared accessions and breeding lines with mungbean breeders worldwide (Schreinemachers et al. 2014).

International collaboration has always been a key feature of the various mungbean improvement programs in Asia and the World Vegetable Center has played an important role in connecting national programs, sharing germplasm, and testing advanced breeding lines in different countries. Early success was achieved in the early 1980s when researchers crossed climate-resilient and disease-resistant (powdery mildew and Cercospora leaf spot) lines from India with high yielding, early maturing and uniform maturing lines from the
Philippines. These crosses were tested in international mungbean trials and two lines were identified as particularly promising (VC1973A and VC2778A), which were released as KPS1 and KPS2 in Thailand and became dominant mungbean varieties in Thailand, China (released as Zhong Lu \#1 and E Lu \#2, respectively), and several other countries (Shanmugasundaram et al. 2009).

During the 1990s, the focus of the WorldVeg mungbean breeding program expanded to include resistance to mungbean yellow mosaic disease (MYMD), which had become the major constraint to mungbean production in large parts of South Asia and Myanmar, though not in other parts of Southeast Asia. As part of a shuttle breeding program between Thailand and Pakistan that was financially supported by the UK government, the Nuclear Institute for Agriculture and Biology (NIAB) in Pakistan was the first to report MYMD resistance, which they had obtained through the irradiation (mutation breeding) of a local variety. NIAB and the World Vegetable Center collaborated to cross these resistant lines with KPS1, which after several generations led to two advanced MYMD-resistant lines: NM92 (standing for NIAB Mungbean 1992) and NM94. WorldVeg then introduced these lines to other countries in South Asia and promoted them to farmers. The main scaling method was seed multiplication of elite lines through the establishment of seed villages, wherein farmers produced their own seed and shared it with others (Shanmugasundaram et al. 2009).

Several impact studies were conducted in the mid-1990s when the success of improved mungbean varieties became clear. Ali et al. (1997) surveyed three major mungbean producing districts of Punjab province of Pakistan and found that $90 \%$ had adopted improved mungbean varieties, with NM92 adopted by $51 \%$ of farmers. The improved varieties had $55 \%$ higher crop yield and the economic benefit was estimated to be US\$ 20 million per year. Weinberger (2005) studied the potential impact of increased mungbean yield on iron consumption and female worker productivity in Pakistan and showed that the improved mungbean varieties made an important contribution to economic development. Further 
evidence of the nutritional benefit of mungbean consumption was reported by Vijayalakshmi et al. (2003) for India. For Bangladesh, Hossain et al. (2003) found that the area under BARI Mung-2 increased from 3\% of the sown area in 1988 to $35 \%$ in 1998 . Their study estimated that mungbean research and extension gave an internal rate of return of $34 \%$. More recently, Haque et al. (2014) studied the adoption of improved mungbean varieties in Jessore, Kushtia and Barisal districts and found that NM92 (locally known as BARI Mung-5) and BARI Mung- 4 were the most popular varieties, used by $49 \%$ and $24 \%$ of farmers, respectively.

Despite evidence for adoption and impact in the mid-1990s and early 2000 s, there is little information about the adoption rates at national levels. It is largely unknown to what extent NM92 and NM94 have been replaced by more recent varieties and what role international mungbean breeding has played in these. Earlier studies were not nationally representative and focused on areas favorable to mungbean production, which may have overestimated the adoption of improved varieties.

\subsection{Use of expert elicitation}

The adoption of improved technologies is a key indicator for the economic impact of agricultural research. Tracking adoption rates over time requires a straightforward and inexpensive method that can be regularly repeated. Farm surveys are not very suitable to do this when farmers recycle their seed or rely on informal seed systems (Maredia et al. 2016), as many mungbean farmers do. Recent studies have collected plant or grain samples and applied DNA analysis to compare cultivated populations against a DNA library of released varieties (e.g. Floro et al. 2018; Rabbi et al. 2015; Yigezu et al. 2019; Wossen et al.2018). Such a method is scientifically robust, but costly to apply on a regular basis at a sub-continental scale.

The project "Diffusion and Impact of Improved Varieties in Africa (DIIVA)" (2010-2013) made an important contribution to the methods for quantifying adoption rates of improved varieties (Walker and Alwang 2015). The project covered 20 food crops and 30 countries using expert elicitation. Expert elicitation is a systematic method using repetitive and independent questioning of a panel of expert informants and is based on the Delphi method (Dalkey and Helmer 1963). The essence of the Delphi method is that a panel of experts answers questionnaires in two or more rounds with results summarized after each round and the panel revising its answers based on the anonymized estimates and judgments of the other experts.

Several previous studies have applied expert elicitation to quantify variety-specific adoption rates. For instance, Rashid and Hossain (2016) used the method to quantify the adoption of improved wheat varieties in Bangladesh, Shah et al. (2015) used it on wheat, chickpea, maize and rice in Pakistan, Tsusaka et al. (2015) applied it to improved rice varieties in
Bangladesh, Bhutan, India, Nepal, and Sri Lanka, and Ochieng et al. (2019) used it on improved amaranth varieties in Kenya and Tanzania. Comparing expert elicitation results with those of farm household surveys, Tsusaka et al. (2015) showed that expert elicitation provides close estimates of the area planted to modern varieties with estimates being more accurate when data are collected from subnational units and then aggregated to obtain a national estimate. They also noted that having enough experts with knowledge about varieties and a variety turnover rate that is not too high are important preconditions for successfully applying the method (Tsusaka et al. 2015). Both conditions were confidently met in this study.

Previous applications had a rather narrow focus on the adoption of improved varieties, which is a drawback because improved varieties are often adopted in combination with other technologies. Our study therefore expanded the method to include the following agronomic practices of relevance to mungbean: (a) seed treatment methods; (b) agronomic practices including line sowing and use of mineral fertilizers, chemical pesticides and irrigation; (c) use of mechanization for plowing, sowing, weeding, harvesting and threshing; and (d) control of bruchid beetles (Callosobruchus sp.) in stored mungbean grains through various methods (phosphine tablets, insecticide sprays, use of botanicals or use of hermetic storage bags).

\subsection{Procedure applied}

The study closely followed the expert elicitation guidelines as documented by the DIIVA project (Maredia and Reyes 2014). We defined an improved variety as "a variety developed by breeders in the formal system. It represents an output or contribution of the national and/or international public and private sector research systems" (Maredia and Reyes 2014: 3). The study conducted the following eight steps to collect and verify data:

1. A general study protocol and data entry form were developed for all countries to ensure data consistency across locations.

2. Secondary data on mungbean production and planting area were collected for each country at disaggregate levels (e.g. province or district) and used to identify 4-5 locations with the largest mungbean area per country, as shown in Fig. 1.

3. Experts (5-20 persons) were identified for each location and generally included agricultural researchers, extension officers, seed dealers, NGO staff, representatives of farm organizations, seed companies, and state seed corporations. 


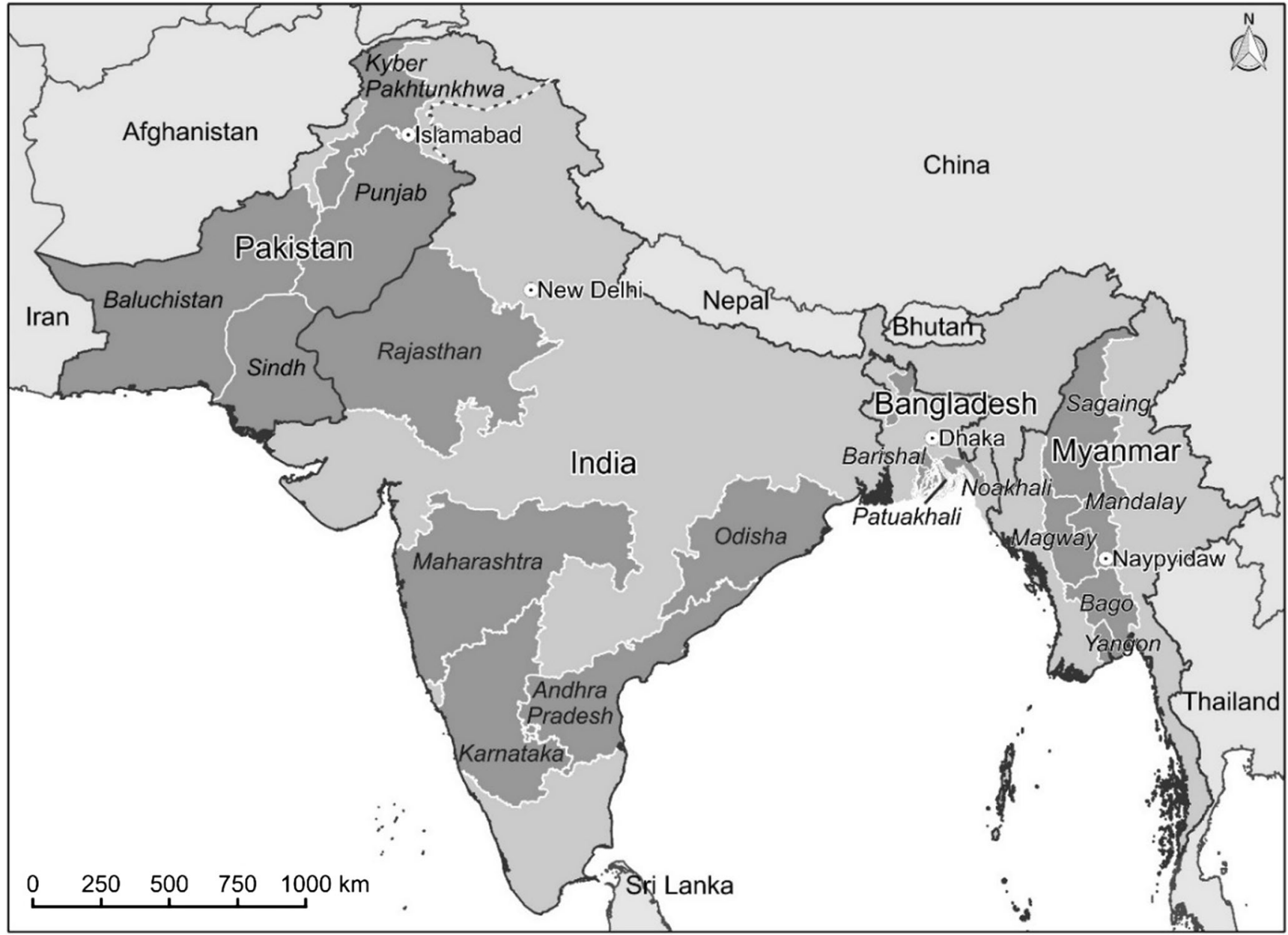

Fig. 1 Map of the four study countries showing the subnational units included

4. Invitations were sent to each expert describing the purpose and the importance of the study and asking them to complete the first-round questionnaire form and to bring it to the meeting. The questionnaires were in English, except for Myanmar where the questionnaire was in Burmese.

5. Expert panel meetings were convened locally in each region, except for Pakistan where the experts were invited to a single one-day meeting in the capital and regional estimates were made in parallel groups. The facilitator explained the purpose and the importance of the study and the procedure to be used. Experts put their estimates of adoption rates on cards and pinned them on a board. After all experts had revealed their estimates a facilitated discussion followed in which participants were encouraged to revisit their initial responses and reach consensus. Participants jointly filled out a second questionnaire at the end.

6. A final estimate for each location and each country was made and documented in a report, which was shared with selected key informants for feedback. The researchers followed-up by phone and the country reports were finalized after all feedback had been received.
7. For each variety identified through this process, additional data were collected about the year of release, the institutional source, varietal traits, the role of NARS and the role of the World Vegetable Center. All data were collected between June and December 2017.

8. The number of farmers adopting improved mungbean varieties was estimated as the planted area under improved mungbean varieties divided by the average planted area per mungbean farmer. Country averages were calculated by applying area-based weights to the consensus estimates per location. Similarly, an average over all countries was calculated using national mungbean areas as weights.

The data generated and analyzed during the current study are available from the corresponding author on request.

\section{Results}

This study covered $100 \%$ of the mungbean production areas in Pakistan, 99\% in Bangladesh, 88\% of the area in Myanmar, 
and $68 \%$ of the area in India. Overall, the study covered $75 \%$ of the regions' total mungbean area of 5.4 million hectares.

\subsection{Varietal adoption}

Of the surveyed mungbean area across the region, $84 \%$ was planted to improved varieties (Table 2). Improved varieties were planted on $94 \%$ of the mungbean area in Pakistan, $89 \%$ in Myanmar, $82 \%$ in India, and $72 \%$ in Bangladesh. However, there were important subnational variations (see Annex Table 5). For India, the adoption of improved varieties in Odisha state was only $20 \%$ while it was $95 \%$ for Andhra Pradesh and $90 \%$ for Rajasthan (the largest mungbean growing state). In Bangladesh, the adoption of improved varieties was relatively low in Noakhali region $(45 \%)$, but $72 \%$ for Patuakhali, which is the largest producer. In Myanmar, the adoption of improved varieties was $84 \%$ in the Central Dry Zone (Magway, Mandalay and Sagaing), but $99 \%$ in the delta region (Yangon and Bago).

Our study recorded a total of 53 improved mungbean varieties currently grown by farmers in the four countries with 28 cultivated varieties recorded for India, which reflects the fact that many Indian states have their own mungbean breeding programs. Annex Table 6 lists the top-10 mungbean varieties per country. The two most popular varieties in each country were found to contain germplasm that originated from the World Vegetable Center. In total, there were 19 currently used varieties that contained such germplasm (3 in India, 5 in Myanmar, 5 in Pakistan, and 6 in Bangladesh).

In Pakistan, $93 \%$ of the mungbean area was planted to varieties that contained genetic material developed at the World Vegetable Center (Table 2). This was $77 \%$ in Myanmar, $67 \%$ in Bangladesh and $27 \%$ in India. There are an estimated 0.50 million mungbean farmers in India benefitting from WorldVeg material and a further 0.43 million in Myanmar. In total, it is estimated that WorldVeg material was planted on 1.8 million hectares and reached 1.2 million mungbean farmers.

The success of the WorldVeg international mungbean breeding program in reaching farmers is largely the result of the advanced breeding lines NM92 and NM94, which were the first sources of MYMD-resistance and were jointly developed by WorldVeg and NIAB in Pakistan. NM94 is the most popular mungbean variety in Bangladesh (where it is known as BARI Mung-6) and Myanmar (known as Yezin-11) and the second-most popular variety in India (SML 668) where it is grown in Odisha (8\% of planted area) and Rajasthan (15\%). In Pakistan, AZRI-06 currently dominates, which has NM92 as one of its parents. Overall, NM92 and NM94-related material was planted on $21 \%$ of the mungbean area across the four countries studied.

\subsection{Adoption of agricultural practices}

The use of certified seed was found to be low in all four countries, reflecting farmers' practice of recycling seed from their own grain harvest and purchasing seed from the open grain market. On average, farmers bought new seed every 3 cropping cycles (Table 3). In Myanmar, the use of certified seed was more common in the Central Dry Zone $36 \%$ of seed) than in the delta region (1\%). However, further probing of local experts showed that the term 'certified seed' may have been misunderstood as simply meaning 'quality seed' and some experts thought that the actual number for the Central Dry Zone should be closer to $3 \%$. In India, the use of certified seed was higher in Andhra Pradesh (58\%) than in the other states and particularly low in Odisha $(15 \%)$ and Rajasthan $(12 \%)$. For India, experts mentioned that in addition to
Table 2 Use of improved varieties and role of the World Vegetable Center, 2016-2017

\begin{tabular}{llllll}
\hline & Bangladesh & India & Myanmar & Pakistan & Total \\
\hline All improved varieties: & & & & & \\
- Number of varieties & 9 & 28 & 9 & 7 & 53 \\
- Share in total area planted (\%) & 72 & 82 & 89 & 94 & 84 \\
- Area planted (1000 ha) & 125 & 2144 & 948 & 169 & 4026 \\
- Farmers using (1000s) & 108 & 1531 & 499 & 192 & 2782 \\
WorldVeg-related varieties: & & & & & \\
- Number of varieties & 6 & 3 & 5 & 5 & 19 \\
- Share in total area planted (\%) & 67 & 27 & 77 & 93 & 45 \\
- Area planted (1000 ha) & 117 & 697 & 822 & 166 & 1802 \\
- Farmers using (1000s) & 101 & 498 & 433 & 189 & 1245 \\
\hline
\end{tabular}

Data for India and Myanmar refer to the subnational units covered by this study ( $68 \%$ of total area for India, $88 \%$ for Myanmar), while data for Pakistan and Bangladesh cover 100\% of these countries' mungbean area. The actual area planted under improved varieties and the number of farmers using these will therefore be higher for India and Myanmar 
Table 3 Use of agronomic practices in mungbean production, in percent of farmers, 2016-2017

\begin{tabular}{llllll}
\hline Agronomic practice & Bangladesh & India & Myanmar & Pakistan & Total \\
\hline Use of certified seed (\% of seed) & 18 & 18 & 23 & 12 & 19 \\
Average varietal age (years) & 16 & 15 & 13 & 9 & 14 \\
Seed replacement rate (cropping cycles) & 2 & 3 & 4 & 3 & 3 \\
Seed treatment with: & & & & & \\
$\quad$ - Insecticides & 0 & 30 & 26 & 0 & 27 \\
- Fungicides & 1 & 38 & 29 & 2 & 33 \\
- Biopesticides (e.g. Trichoderma) & 0 & 10 & 0 & 0 & 7 \\
- Biofertilizers (e.g. Rhizobium) & 0 & 14 & 2 & 1 & 10 \\
Line sowing & 3 & 82 & 48 & 59 & 71 \\
Irrigation (times) & 0.1 & 0.4 & 1.6 & 2.8 & 0.8 \\
Mineral fertilizers, basal dressing & 52 & 57 & 62 & 37 & 57 \\
Mineral fertilizers, top dressing & 12 & 3 & 33 & 0 & 10 \\
Mineral fertilizers, foliar & 0 & 3 & 99 & 31 & 25 \\
Chemical insecticides/fungicides & 87 & 50 & 97 & 94 & 63 \\
Herbicides (defoliator) & 0 & 2 & 0 & 1 & 1 \\
Use of mechanization for: & & & & & 83 \\
- Land preparation & 96 & 91 & 83 & 100 & 89 \\
- Sowing & 1 & 74 & 0 & 58 & 55 \\
- Weeding & 0 & 4 & 0 & 20 & 4 \\
- Harvesting & 0 & 14 & 0 & 1 & 10 \\
- Threshing & & 83 & 82 & 96 & 80 \\
\hline
\end{tabular}

certified seed there is Truthful Seed (TFS), which was not captured in the questionnaire, but its use was reported as common in Maharashtra and Karnataka.

The average age of varieties used by farmers ranged from 9 years in Pakistan to 16 years in Bangladesh. This points to the fact that open-pollinated varieties scaled through public sector seed systems are slow to diffuse. In comparison, Tsusaka et al. (2015) also found that it takes more than a decade for farmers in South Asia to adopt a new rice variety after its release.

Seed treatment with insecticides and fungicides can be an effective method to deal with certain pests such as white flya vector for MYMD, and for control of seed-borne and root rot pathogens. Not many farmers use such seed treatment with the exceptions of Rajasthan (India) and Magway (Myanmar) where $50 \%$ of farmers use either insecticides or fungicides to treat seed. The adoption of fungicide seed treatment is high in Andhra Pradesh (90\%) and Karnataka (45\%) in India. Further, in India (all states except Odisha), about $10 \%$ of the growers use biopesticides such as Trichoderma for seed treatment. However, seed treatment with chemical or biological pesticides is rarely done in Pakistan and Bangladesh, although the majority of farmers do spray chemical pesticides at later stages of the crop. Finally, seed treatment with biofertilizers such as Rhizobium can promote nodulation and plant growth. This is practiced in Karnataka (10\% of farmers), Rajasthan
(20\%) and Mandalay (10\%), but adoption levels are near zero anywhere else.

Mungbean production is mechanized to varying degrees. Land preparation is nowadays done by tractor nearly everywhere and also threshing of bean pods is mostly done mechanically, except in Bangladesh and Odisha, India where all mungbean is still threshed by hand. Sowing is largely mechanized in Pakistan and India, but not in the other countries. Machine weeding is used in Punjab's Thal region (25\% of farmers) and in India's Rajasthan (8\%) but is absent anywhere else. Machine harvesting using combine harvesters was found to be relatively common in Andhra Pradesh (70\% of farmers), Karnataka (25\%) and Rajasthan (15\%), but this is rare elsewhere. In general, mungbean production in Bangladesh is the least mechanized while it is most mechanized in India and Pakistan.

The use of mineral fertilizers and chemical pesticides is widespread in Myanmar, particularly in the Central Dry Zone. Fertilizers are most commonly applied at the time of sowing (i.e. basal dressing), which saves labor time. Foliar application of mineral fertilizers in liquid form is common in Andhra Pradesh ( $75 \%$ of farmers), all regions of Myanmar (>90\%), and Punjab's Thal region (40\%), but not elsewhere. The use of chemical pesticides was common nearly everywhere. Desiccants (i.e. herbicides) can also be used in mechanical mungbean production to kill the plant and stimulate ripening, but our study shows that adoption rates are close to zero. 
Bruchid beetles are the main pests in stored mungbean. Infestation often happens in the field, but the beetles can rapidly multiply in storage, particularly under humid conditions. In Pakistan, $70 \%$ of the farmers use phosphine tablets, but virtually no other method (Table 4). In Bangladesh and Myanmar, about $28 \%$ use phosphine tables and $20-35 \%$ use botanicals. Common botanicals include neem leaves, neem oil and castor oil. In Myanmar these methods are used by the storage agents as farmers do not store mungbean on their farms. In India, the use of any control methods is generally low, but some experts said that farmers sprinkle ash or sand in the storage bins, which was not captured in the questionnaire. Hermetic storage bags are not used for mungbean in any country; its use may be more common in rice. The use of chemical insecticides and fungicides in stored mungbean was uncommon, which may indicate that farmers are aware of its health risks if the beans are used for human consumption.

\section{Discussion}

\subsection{Summary of key results}

Mungbean is an important crop in Bangladesh, India, Myanmar and Pakistan with a total planted area of 5.4 million hectares and 3.7 million smallholder farmers involved (2015-2016). This study covered about $75 \%$ of this area and found that improved mungbean varieties were planted on $84 \%$ of it with local or traditional varieties occupying the remaining $16 \%$. The use of improved varieties was low in some locations such as Odisha in India (20\%), Noakhali in Bangladesh (45\%), and Sindh \& Baluchistan in Pakistan $(25 \%)$.

World Vegetable Center contributed to the success of improved mungbean varieties by connecting the national mungbean breeding programs across Asia, crossing lines with desirable traits from different locations, introducing the best performing ones into new locations, supporting quality seed supplies, and promoting farm-level adoption. Intensive collaboration with the national programs has been a key factor behind the success. As a result, this study found that $93 \%$ of the mungbean area in Pakistan, $77 \%$ in Myanmar, 67\% in Bangladesh, and $27 \%$ in India are planted to varieties that contain improved germplasm developed by the World Vegetable Center in partnership with national systems.

In India, only 3 out of 28 cultivated varieties were related to WorldVeg. A possible explanation is that many states in India have their own mungbean breeding program and each promotes its own varieties. The other countries have fewer programs, which makes collaboration easier. Therefore, to better assist farmers in India, the World Vegetable Center will need to try and collaborate better with state-level mungbean programs. These programs should have a strong interest in collaboration because, of the 30 improved varieties identified in this study for India, only $51 \%$ had resistance against MYMD, 24\% had powdery mildew resistance, and $10 \%$ had Cercospora leaf spot resistance, which are the three most important mungbean diseases. The lack of these key traits in the varieties cultivated may help to explain the low crop yields in India as compared to the other countries.

For India and Myanmar, the actual number of farmers benefitting from the work of the World Vegetable Center may be higher than estimated because our study covered only $88 \%$ of the planted area in Myanmar and $68 \%$ for India. We selected the largest mungbean growing states for our study and these may not be representative for the other mungbean growing states. The estimates were therefore not extrapolated to the other states; doing this, would otherwise have increased the total number of farm households reached to 1.5 million.

\subsection{Reflection on the use of expert elicitation}

The adoption of improved agricultural technologies is an important indicator of the impact of agricultural research and this study showed that it is straightforward to quantify adoption rates using expert elicitation. A novelty of this study was to quantify not only the
Table 4 Control of bruchid beetles in stored mungbean, in \% of farmers, 2016-2017

\begin{tabular}{llllll}
\hline & Bangladesh & India & Myanmar & Pakistan & Total \\
\hline Use of phosphine tablets & 28 & 4 & 27 & 70 & 12 \\
Insecticide/fungicide sprays & 0 & 2 & 1 & 3 & 2 \\
Botanicals & 20 & 11 & 35 & 0 & 17 \\
Hermetic storage bags & 0 & 0 & 0 & 0 & 0 \\
\hline
\end{tabular}

For Myanmar this refers to the $\%$ of storage agents (brokers, middlemen) as farmers do not store mungbean on their farm 
adoption of improved varieties but also of other agricultural practices, which provides a more comprehensive overview of the status of technology adoption. However, whereas farmers can usually not tell the name of the variety they sow, it will be easier for them to tell the adoption of the other practices.

Low cost and the ability to cover large geographical areas are the main advantages of expert elicitation. Several of such studies have covered multiple countries (e.g. Tsusaka et al. 2015 covered five countries in South Asia and the DIIVA project covered 20 crops in 30 countries) while DNA fingerprinting studies are still limited to single-country or subnational pilot studies. The total cost of doing this study for four countries (including 19 expert meetings, subsequent data analysis and write-up) was about US\$120,000, which may guide future studies. Another strength of the method is that the involvement of local experts in the estimation gives them ownership of the findings. This is important as it increases the likelihood that the study results would be used by the relevant public and private organizations to target extension efforts.

However, there are also disadvantages of using expert elicitation, the main ones being a potential low level of accuracy and an unknown confidence interval of the estimates. Tsusaka et al. (2015) found for rice in South Asia that expert panels provided estimates of adoption rates similar to those of farm household surveys, particularly for the dominant varieties. However, comparing expert elicitation with farm surveys and DNA fingerprinting in the case of lentil varieties in Bangladesh, Yigezu et al. (2019) showed that expert panels have a bias toward overestimating the adoption of later-released varieties while underestimating the adoption rate of older varieties. Other recent studies also show that varietal adoption rates estimated from farm surveys may not be accurate (Maredia et al. 2016; Wossen et al. 2018).

The use of DNA fingerprinting is therefore the preferred method of studying varietal adoption, and its large-scale application may become feasible in the future if the cost of genotyping continues to decline. Until then, expert elicitation methods remain useful to monitor the adoption of improved varieties and agronomic practices at a large-scale.

\subsection{Future directions for international mungbean breeding}

Since the 2010s, emphasis in the World Vegetable Center mungbean breeding program was placed on increasing the diversity of cultivated mungbean to reduce the dominance of NM94, which was found to be susceptible to the MYMVurdbean strain prevalent in northern India (Nair et al. 2015,
2017). The Center developed a mungbean mini-core collection of 296 accessions, which gives breeders worldwide easier access to the existing genetic diversity of mungbean (Schafleitner et al. 2015). New sources of resistance (for example, ML1628) were identified, including from a related species (Vigna mungo L. Hepper) (Nair et al. 2017) and new lines were developed with resistance to all major strains of MYMV. In addition, the program developed lines with resistance to bruchids (Nair et al. 2015). WorldVeg leads an International Mungbean Improvement Network funded by the Australian Centre for International Agricultural Research (ACIAR), with partners from Bangladesh, India, Myanmar and Australia. Activities of this network include sharing of germplasm and new improved lines, implementation of an integrated breeding platform, and capacity building.

\section{Conclusions}

Improved mungbean varieties are widely adopted by farmers in Bangladesh, India, Myanmar and Pakistan. International mungbean breeding research, as conducted by the World Vegetable Center in partnership with national mungbean programs, has made an important contribution to the spread of these improved varieties and benefits about 1.2 million farm households. However, further efforts are needed to promote improved varieties with more comprehensive resistance against the main pests and diseases as well as abiotic stresses such as heat, drought and salinity. There are also clear opportunities to increase mungbean yields in particular locations through the promotion of good agricultural practices such as the use of certified seed, seed treatment, line sowing, and good storage practices while the adoption of mechanization in various stages of production (sowing, weeding, harvesting, and threshing) can improve profits where the cost of farm labor is high.

Acknowledgments This study was supported by UK aid through the Department for International Development (DFID), by the Federal Ministry for Economic Cooperation and Development, Germany and by other core donors to the World Vegetable Center: Republic of China (Taiwan), United States Agency for International Development (USAID), Australian Centre for International Agricultural Research (ACIAR), Thailand, Philippines, Korea, and Japan. Figure 1 was created by Peter Elstner. We thank colleagues at the participating organizations for their contributions and support. We are grateful to the many mungbean experts who informed the study. The paper benefited from the comments of the editors and reviewers of this journal.

\section{Compliance with ethical standards}

Conflict of interest The authors declare that they have no conflict of interest. 


\section{Annex 1}

Table 5 Adoption of improved mungbean varieties by country and subnational unit, 2016-2017

\begin{tabular}{|c|c|c|c|c|c|c|c|}
\hline \multirow{2}{*}{$\begin{array}{l}\text { Country / Subnational } \\
\text { location }\end{array}$} & \multirow{2}{*}{$\begin{array}{l}\text { Expert informants } \\
\text { (persons) }\end{array}$} & \multirow{2}{*}{$\begin{array}{l}\text { Planted area } \\
\text { (ha) }\end{array}$} & \multirow{2}{*}{$\begin{array}{l}\text { Grain yield } \\
(\mathrm{kg} / \mathrm{ha})\end{array}$} & \multirow{2}{*}{$\begin{array}{l}\text { Improved } \\
\text { varieties (\% area) }\end{array}$} & \multicolumn{3}{|c|}{ WorldVeg-related varieties } \\
\hline & & & & & \# varieties & $\%$ area adopted & $\begin{array}{l}\text { \# farmers } \\
\text { reached }(1000)^{\mathrm{a}}\end{array}$ \\
\hline Bangladesh & 80 & 175 & 1030 & 72 & 6 & 67 & 101 \\
\hline - Barisal & 20 & 40 & 1118 & 80 & 4 & 70 & 24 \\
\hline - Noakhali & 20 & 15 & 631 & 45 & 3 & 44 & 6 \\
\hline - Patuakhali & 20 & 118 & 1051 & 72 & 4 & 69 & 70 \\
\hline - Rangpur & 20 & 1 & 714 & 85 & 3 & 71 & 0 \\
\hline India & 87 & 3828 & 418 & 82 & 3 & 27 & 498 \\
\hline - Andhra Pradesh & 16 & 212 & 646 & 95 & 1 & 5 & 8 \\
\hline - Karnataka & 19 & 357 & 157 & 85 & 1 & 2 & 5 \\
\hline - Maharashtra & 25 & 385 & 187 & 90 & 0 & 0 & 0 \\
\hline - Odisha & 11 & 285 & 294 & 20 & 3 & 12 & 24 \\
\hline - Rajasthan & 16 & 1373 & 439 & 90 & 3 & 47 & 461 \\
\hline Myanmar & 67 & 1209 & 1320 & 89 & 5 & 77 & 406 \\
\hline - Bago & 15 & 231 & 863 & 99 & 5 & 79 & 90 \\
\hline - Magway & 12 & 313 & 1351 & 80 & 4 & 72 & 111 \\
\hline - Mandalay & 12 & 136 & 573 & 81 & 2 & 80 & 54 \\
\hline - Sagaing & 14 & 230 & 1048 & 90 & 2 & 90 & 103 \\
\hline - Yangon & 14 & 151 & 1380 & 100 & 3 & 65 & 49 \\
\hline Pakistan & 25 & 179 & 728 & 94 & 2 & 30 & 61 \\
\hline - Khyber Pakhtunkhwa & 3 & 12 & 612 & 90 & 0 & 0 & 0 \\
\hline - Punjab (Pothwar) & 7 & 5 & 304 & 99 & 1 & 35 & 2 \\
\hline - Punjab (Thal) & 6 & 139 & 752 & 98 & 2 & 29 & 46 \\
\hline - Punjab (other) & 4 & 15 & 567 & 99 & 2 & 77 & 13 \\
\hline - Sindh \& Baluchistan & 5 & 8 & 1035 & 25 & 1 & 2 & 0 \\
\hline
\end{tabular}

Planted area and grain yield based on national statistics for 2015-2016 (see Table 1 for sources). Adoption of improved varieties at the national level calculated as the average of the subnational estimates weighted by planted area

${ }^{\text {a }}$ Calculated over the subnational locations that were surveyed, conservatively assuming zero adoption in all other areas 
Table 6 Top-10 improved mungbean varieties per country, in \% of area planted, 2016-2017

\begin{tabular}{|c|c|c|c|c|c|c|}
\hline & \multicolumn{3}{|l|}{ Bangladesh } & \multicolumn{3}{|l|}{ India } \\
\hline & Variety & Year & $\%$ & Variety & Year & $\%$ \\
\hline 1 & BARI Mung- $6 *$ & 2003 & 48 & IPM 2-3* & 2009 & 16 \\
\hline 2 & BARI Mung-5 * & 1997 & 10 & SML $668 *$ & 2002 & 9 \\
\hline 3 & BARI Mung- $2 *$ & 1987 & 7 & Other varieties & - & 7 \\
\hline 4 & Binamoog-5 $*$ & 1998 & 2 & GM 4 & 2003 & 6 \\
\hline 5 & Binamoog-8 & 2010 & 2 & NUL 7 & 2009 & 5 \\
\hline 6 & BARI Mung-3 & 1996 & 1 & LGG 460 & 1997 & 4 \\
\hline 7 & Other varieties & - & 1 & Utkarsha & 2016 & 4 \\
\hline 8 & Binamoog- $6 *$ & 2005 & $<1$ & RMG 492 & 2003 & 4 \\
\hline 9 & BARI Mung-4 * & 1996 & $<1$ & China mung & 1975 & 4 \\
\hline \multirow[t]{3}{*}{10} & Binamoog-7 & 2005 & $<1$ & Shiny mung & 1975 & 3 \\
\hline & \multicolumn{3}{|l|}{ Myanmar } & \multicolumn{3}{|l|}{ Pakistan } \\
\hline & Variety & Year & $\%$ & Variety & Year & $\%$ \\
\hline 1 & Yezin $11 *$ & 2007 & 39 & AZRI 06 * & 2006 & 59 \\
\hline 2 & Yezin $14 *$ & 2011 & 26 & NM $11 *$ & 2011 & 29 \\
\hline 3 & Yezin 1 & 1976 & 9 & Inqilab Mung * & 2013 & 3 \\
\hline 4 & Yezin $9 *$ & 2003 & 7 & Sono Mung * & 2015 & $<1$ \\
\hline 5 & MAS $1 *$ & 2009 & 5 & AEM96 & 1997 & $<1$ \\
\hline 6 & Mya Kya Mon & 1975 & 1 & NM $16 *$ & 2016 & $<1$ \\
\hline 7 & Zotkalay & 1988 & $<1$ & Dera Mung-2009 & 2009 & $<1$ \\
\hline 8 & Yezin $6 *$ & 1993 & $<1$ & Other varieties & - & $<1$ \\
\hline 9 & Yezin 4 & 1987 & $<1$ & - & & \\
\hline 10 & - & & & - & & \\
\hline
\end{tabular}

In $\%$ of area planted for the surveyed locations

* Variety with WorldVeg-developed genetic material in its pedigree

Open Access This article is distributed under the terms of the Creative Commons Attribution 4.0 International License (http:// creativecommons.org/licenses/by/4.0/), which permits unrestricted use, distribution, and reproduction in any medium, provided you give appropriate credit to the original author(s) and the source, provide a link to the Creative Commons license, and indicate if changes were made.

\section{References}

Ali, M., Malik, I. A., Sabir, H. M., \& Ahmad, B. (1997). The mungbean green revolution in Pakistan. In Technical bulletin 24 (66 p). AVRDC, Shanhua, Taiwan: ROC.

Bangladesh Bureau of Statistics (2015). Statistical yearbook of Bangladesh. Statistics division, Ministry of Planning, Government of the Peoples' Republic of Bangladesh.

Bisht, I., Mahajan, R., \& Patel, D. (1998). The use of characterisation data to establish the Indian mungbean core collection and assessment of genetic diversity. Genetic Resources and Crop Evolution, 45, 127 133. https://doi.org/10.1023/A:1008670332570.
Dalkey, N., \& Helmer, O. (1963). An experimental application of the DELPHI method to the use of experts. Management Science, 9, 458-467.

Directorate of Economics and Statistics (2017). Area, production and yield estimates of Mungbean in India 2015-16. Directorate of Economics and Statistics, Department of Agriculture, Cooperation and Farmers Welfare, Ministry of of Agriculture and Farmers Welfare, Government of India, Available at: http://eands.dacnet. nic.in/APY_96_To_06.htm (accessed March 2018), New Dehli.

Floro, V. O., Labarta, R. A., Becerra López-Lavalle, L. A., Martinez, J. M., \& Ovalle, T. M. (2018). Household determinants of the adoption of improved cassava varieties using DNA fingerprinting to identify varieties in farmer fields: A case study in Colombia. Journal of Agricultural Economics, 69, 518-536. https://doi.org/10.1111/ 1477-9552.12247.

HanumanthaRao, B., Nair, R. M., \& Nayyar, H. (2016). Salinity and high temperature tolerance in mungbean [Vigna radiata (L.) Wilczek] from a physiological perspective. Frontiers in Plant Science, 7. https://doi.org/10.3389/fpls.2016.00957.

Haque, M., Miah, M. M., Ali, A., \& Luna, A. (2014). Adoption of mungbean technologies and technical efficiency of mungbean (Vigna radiata) farmers in selected areas of Bangladesh. Bangladesh Journal of Agricultural Research, 39, 113-125. https://doi.org/10.3329/bjar.v39i1.20149.

Hossain, M. I., Sattar, M. A., Mia, M. A. M., Begum, S. N., \& Khan, M. S. K. (2003). Impact of mungbean research and extension in Bangladesh. Pakistan Journal of Biological Sciences, 6, 17331740.

Maredia, M., Reyes, B. (2014). Guidelines for collecting varietal release and adoption data. Objective 2.1. "Organize the collection of crop germplasm improvement research related direct outcomes", Strenghtening impact assessment in CGIAR (SIAC) project, Available from: https://ispc.cgiar.org/sites/default/files/docs/ Guidelines-SIAC21-Activity_v7-4-25-14.pdf. Accessed April 2019.

Maredia, M. K., Reyes, B. A., Manu-Aduening, J., Dankyi, A., Hamazakaza, P., Muimui, K., Rabbi, I., Kulakow, P., Parkes, E., Abdoulaye, T., Katungi, E. \& Raatz, B. (2016). Testing alternative methods of varietal identification using DNA fingerprinting: Results of pilot studies in Ghana and Zambia. MSU International Development Working Paper No. 149, October 2016, Michigan State University.

Miah, M. A. M., Akter, M. S., \& Bakr, M. A. (2004). Status of pulses varieties adoption in Bangladesh: A farm level study. Bangladesh Journal of Agricural Economics XXVII, 107-122.

Ministry of Agriculture, Livestock and Irrigation. (2016). Myanmar Agriculture at a Glance 2016. Department of Planning, Ministry of Agriculture, Livestock and Irrigation, Nay Pyi Taw.

Ministry of National Food Security \& Research. (2017). Agricultural statistics of Pakistan 2014-15. Ministry of Food Security and Research. Islamabad: Government of Pakistan.

Nair, R.M., Yan, M.R., Srinivasan, R., Schafleitner, R. (2015). Developing bruchid resistant mungbean varieties SABRAO 13th congress and international conference IPB international convention center, Bogor, Indonesia 14-16 September 2015.

Nair, R. M., Götz, M., Winter, S., Giri, R. R., Boddepalli, V. N., Sirari, A., Bains, T. S., Taggar, G. K., Dikshit, H. K., Aski, M., Boopathi, M., Swain, D., Rathore, A., Anil Kumar, V., Lii, E. C., \& Kenyon, L. (2017). Identification of mungbean lines with tolerance or resistance to yellow mosaic in fields in India where different begomovirus species and different Bemisia tabaci cryptic species predominate. European Journal of Plant Pathology, 149(2), 349-365.

Nair, R. M., Yang, R. Y., Easdown, W. J., Thavarajah, D., Thavarajah, P., Hughes, J., \& Keatinge, J. D. (2013). Biofortification of mungbean (Vigna radiata) as a whole food to enhance human health. Journal of the Science of Food and Agriculture, 93, 1805-1813. 
Ochieng, J., Schreinemachers, P., Ogada, M., Dinssa, F. F., Barnos, W., \& Mndiga, H. (2019). Adoption of improved amaranth varieties and good agricultural practices in East Africa. Land Use Policy, 83, 187194.

Rabbi, I. Y., Kulakow, P. A., Manu-Aduening, J. A., Dankyi, A. A., Asibuo, J. Y., Parkes, E. Y., Abdoulaye, T., Girma, G., Gedil, M. A., Ramu, P., Reyes, B., \& Maredia, M. K. (2015). Tracking crop varieties using genotyping-by-sequencing markers: A case study using cassava (Manihot esculenta Crantz). BMC Genetics, 16, 115.

Rashid, M. A., \& Hossain, T. M. B. (2016). Adoption of wheat varieties in Bangladesh: Expert elicitation approach. Bangladesh Journal of Agricultural Resesaerch, 41, 491-505.

Schafleitner, R., Nair, R. M., Rathore, A., Wang, Y.-w., Lin, C.-y., Chu, S.-h., Lin, P.-y., Chang, J.-C., \& Ebert, A. W. (2015). The AVRDC The world vegetable center mungbean (Vigna radiata) core and mini core collections. BMC Genomics, 16, 344.

Schreinemachers, P., Balasubramaniam, S., Boopathi, N. M., Ha, C. V., Kenyon, L., Praneetvatakul, S., Sirijinda, A., le, N. T., Srinivasan, R., \& Wu, M. H. (2015). Farmers' perceptions and management of plant viruses in vegetables and legumes in tropical and subtropical Asia. Crop Protection, 75, 115-123. https://doi.org/10.1016/j. cropro.2015.05.012.

Schreinemachers, P., Ebert, A., \& Wu, M.-H. (2014). Costing the ex situ conservation of plant genetic resources at AVRDC-the world vegetable center. Genetic Resources and Crop Evolution, 61, 757-773. https://doi.org/10.1007/s10722-013-0070-5.

Schreinemachers, P., Rani, S., \& Kuziyev, B. (2017). Mungbean as a catch crop for dryland systems in Pakistan and Uzbekistan: A situational analysis. Shanhua, Taiwan: World Vegetable Center.

Shah, H., Rani, S., Khan, A.M, Tariq Hassan T, Mittal, S. (2015) Adoption of Improved W Wheat, Maize, Rice and Chickpea Varieties in Pakistan: Synthesis of Background Information, study conducted under the Strengthening Impact Assessment in the CGIAR in Pakistan.

Shanmugasundaram, S., Keatinge, J. D. H., \& d'Arros Hughes, J. (2009). The mungbean transformation. Diversifying crops, defeating malnutrition. In D. J. Spielman \& R. Pandya-Lorch (Eds.), Millions fed: Proven successes in agricultural development (pp. 103-108). Washington, DC: International Food Policy Research Institute.

Tsusaka, T. W., Velasco, M. L., Yamano, T., \& Pandey, S. (2015). Expert elicitation for assessing agricultural technology adoption: The case of improved Rice varieties in south Asian countries. Asian Journal of Agriculture and Development, 12, 19-33.

Vijayalakshmi, P., Amirthaveni, S., Devadas, R. P., Weinberger, K., Tsou, S. C. S., \& Shanmugasundaram, S. (2003). Enhanced bioavailability of iron from mungbeans and its effects on health of schoolchildren. In AVRDC-The world vegetable center, technical bulletin 30. Shanhua: Taiwan.

Walker, T. S., \& Alwang, J. (2015). Crop improvement, adoption and impact of improved varieties in food crops in sub-Saharan Africa. In CABI publishing. Wallingford: U.K.

Weinberger, K. (2005). Assessment of the nutritional impact of agricultural research: The case of mungbean in Pakistan. Food and Nutrition Bulletin, 26, 287-294.

Wossen, T., Abdoulaye, T., Alene, A., Nguimkeu, P., Feleke, S., Rabbi, I. Y., Haile, M. G., \& Manyong, V. (2018). Estimating the productivity impacts of technology adoption in the presence of misclassification. American Journal of Agricultural Economics, 101(1), 1-16.

Yigezu, Y. A., Alwang, J., Rahman, M. W., Mollah, M. B. R., El-Shater, T., Aw-Hassan, A., \& Sarker, A. (2019). Is DNA fingerprinting the gold standard for estimation of adoption and impacts of improved lentil varieties? Food Policy, 83, 48-59. https://doi.org/10.1016/j. foodpol.2018.11.004.

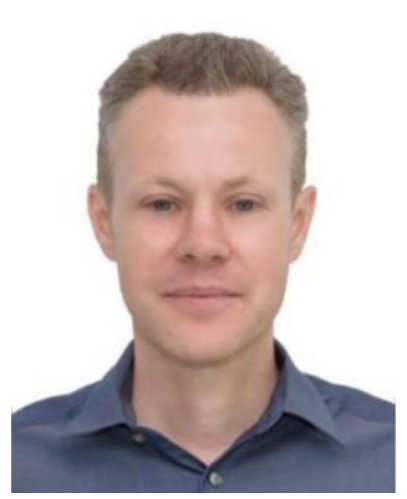

Pepijn Schreinemachers is Lead Scientist - Impact Evaluation at the World Vegetable Center. His expertise is in farming systems research, integrated modeling, and impact evaluation. He holds a $\mathrm{PhD}$ in Agricultural Economics from the University of Bonn, Germany and an MSc in Development Studies from Wageningen University, the Netherlands.

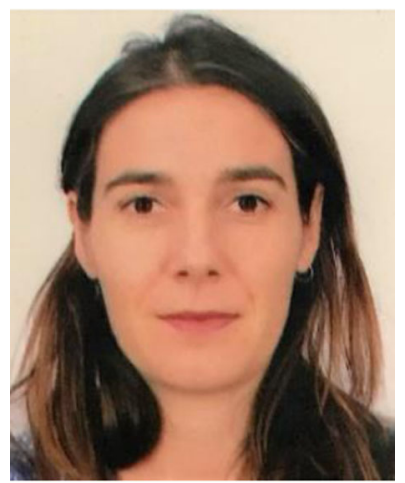

Teresa Sequeros is an international consultant with experience on quantifying the economic impact of development initiatives within the private and public sector. She holds an MSc in Development Studies, specialising in the Economics of Rural Development, from Wageningen University, the Netherlands.

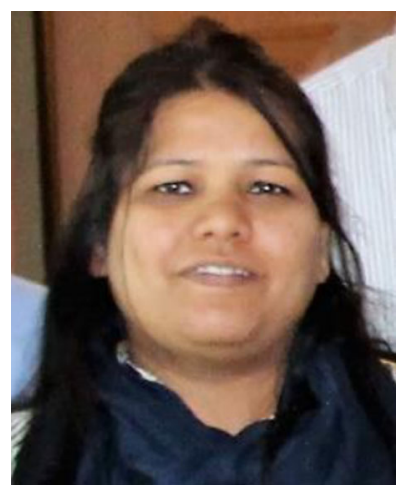

Saima Rani is Scientific Officer at the Agricultural Economics Research Institute, National Agricultural Research Center, Islamabad, Pakistan. She holds an MSc in Economics from the International Islamic University, Islamabad. 


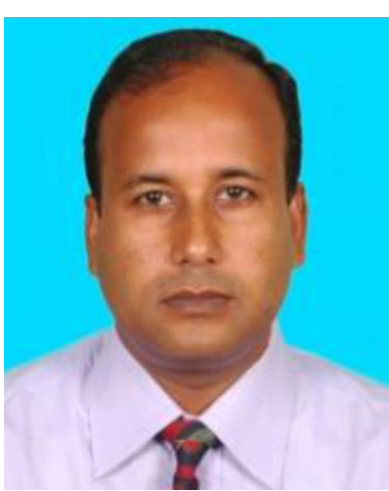

Md. Abdur Rashid is Principal Scientific Officer at the Agricultural Economics Division at Bangladesh Agricultural Research Institute, Gazipur, Bangladesh. He holds a PhD in Agricultural Economics from Bangladesh Agricultural University, Mymensingh, Bangladesh.

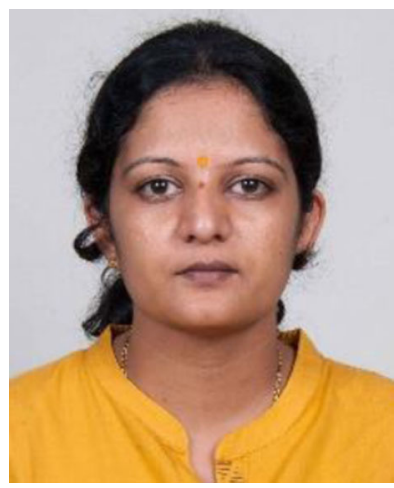

Nithya Vishwanath Gowdru is Assistant Professor at the Centre for Agrarian Studies (CAS) at the National Institute of Rural Development and Panchayati Raj - Ministry of Rural development, Government of India. She holds a $\mathrm{PhD}$ in Agricultural Economics from Humboldt University Berlin, Germany. She also holds an MSc in Rural Development from Ghent University, Belgium and an MSc in Agricultural Economics from University of Agricultural Sciences, GKVK, Bangalore, India.

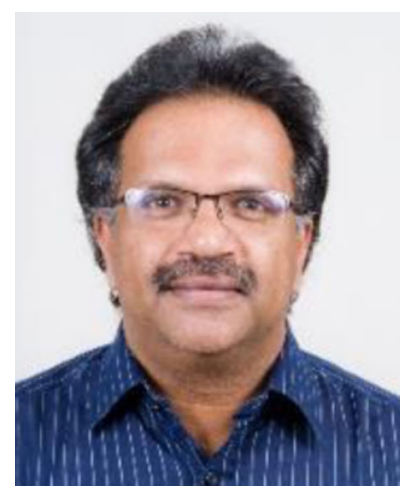

Ramakrishnan Madhavan Nair is Legume Breeder at the World Vegetable Center. His expertise is in plant breeding and genetics. He holds a PhD in Plant Breeding from Kerala Agricultural University, India and a Master's degree in Agriculture with specialisation in Plant Breeding and Genetics from Tamil Nadu Agricultural University, India. He also completed a Professional Management Program at the School of Business, University of Adelaide.

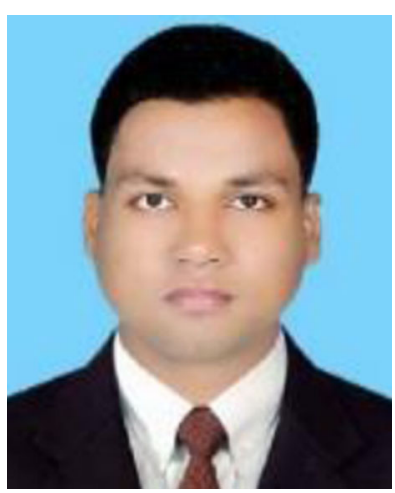

Muhammad Shahrukh Rahman is Scientific Officer at the Agricultural Economics Division of Bangladesh Agricultural Research Institute, Gazipur, Bangladesh. He holds an MSc in Agricultural Economics from Bangladesh Agricultural University, Mymensingh, Bangladesh. 